University of Nebraska - Lincoln

DigitalCommons@University of Nebraska - Lincoln

2006

\title{
North American Prairie Wetlands are Important Nonforested Land-Based Carbon Storage Sites
}

Ned H. Euliss Jr.

USGS Northern Prairie Wildlife Research Center

R. A. Gleason

USGS Northern Prairie Wildlife Research Center, rgleason@usgs.gov

A. Olness

U.S. Department of Agriculture, North Central Soil Conservation Research Laboratory, Morris, MN

R.L. McDougal

Ducks Unlimited Canada, Institute for Wetland and Waterfowl Research, Oak Hammock, MB, Canada

H.R. Murkin

Ducks Unlimited Canada, Institute for Wetland and Waterfowl Research, Oak Hammock, MB, Canada

See next page for additional authors

Follow this and additional works at: https://digitalcommons.unl.edu/usgsnpwrc

Part of the Other International and Area Studies Commons

Euliss, Ned H. Jr.; Gleason, R. A.; Olness, A.; McDougal, R.L.; Murkin, H.R.; Robarts, R.D.; Bourbonniere, R.A.; and Warner, B.G., "North American Prairie Wetlands are Important Nonforested Land-Based Carbon Storage Sites" (2006). USGS Northern Prairie Wildlife Research Center. 23.

https://digitalcommons.unl.edu/usgsnpwrc/23

This Article is brought to you for free and open access by the US Geological Survey at DigitalCommons@University of Nebraska - Lincoln. It has been accepted for inclusion in USGS Northern Prairie Wildlife Research Center by an authorized administrator of DigitalCommons@University of Nebraska - Lincoln. 


\section{Authors}

Ned H. Euliss Jr., R. A. Gleason, A. Olness, R.L. McDougal, H.R. Murkin, R.D. Robarts, R.A. Bourbonniere, and B.G. Warner 


\title{
North American prairie wetlands are important nonforested land-based carbon storage sites
}

\author{
Ned H. Euliss Jr. ${ }^{\text {a,* }}$, R.A. Gleason ${ }^{\text {a }}$, A. Olness ${ }^{b}$, R.L. McDougal ${ }^{c}$, H.R. Murkin ${ }^{c}$, \\ R.D. Robarts ${ }^{\mathrm{d}}$, R.A. Bourbonniere ${ }^{\mathrm{e}}$, B.G. Warner ${ }^{\mathrm{f}}$ \\ ${ }^{\mathrm{a}}$ U.S. Geological Survey, Northern Prairie Wildlife Research Center, Jamestown, ND 58401-7317, USA \\ ${ }^{\mathrm{b}}$ U.S. Department of Agriculture, North Central Soil Conservation Research Laboratory, Morris, MN 56267-1065, USA \\ ${ }^{\mathrm{c}}$ Ducks Unlimited Canada, Institute for Wetland and Waterfowl Research, Oak Hammock, MB, Canada R0C 2ZO \\ ${ }^{\mathrm{d}}$ Environment Canada, National Water Research Institute, Saskatoon, SK, Canada S7N 35H \\ ${ }^{\mathrm{e}}$ Environment Canada, National Water Research Institute, Burlington, ON, Canada L7R 4A6 \\ ${ }^{\mathrm{f}}$ Wetlands Research Centre, University of Waterloo, Waterloo, ON, Canada N2L $3 G 1$
}

Received 7 January 2005; accepted 13 June 2005

Available online 29 August 2005

\begin{abstract}
We evaluated the potential of prairie wetlands in North America as carbon sinks. Agricultural conversion has resulted in the average loss of $10.1 \mathrm{Mg} \mathrm{ha}^{-1}$ of soil organic carbon on over 16 million ha of wetlands in this region. Wetland restoration has potential to sequester $378 \mathrm{Tg}$ of organic carbon over a 10-year period. Wetlands can sequester over twice the organic carbon as no-till cropland on only about $17 \%$ of the total land area in the region. We estimate that wetland restoration has potential to offset $2.4 \%$ of the annual fossil $\mathrm{CO}_{2}$ emission reported for North America in 1990.
\end{abstract}

Keywords: Carbon sequestration; Wetlands; Prairie pothole region; Global climate change

\section{Introduction}

Concern over global climate change has stimulated much interest in identifying existing and potential carbon sinks. Atmospheric-based studies have provid-

\footnotetext{
* Corresponding author. Tel.: +1 701253 5564; fax: +1 701253 5553.

E-mail address: Ned_Euliss@usgs.gov (N.H. Euliss).
}

ed compelling evidence of a large terrestrial carbon sink in the Northern Hemisphere (Tans et al., 1990; Ciais et al., 1995) divided between North America and Eurasia (Schimel et al., 2001). Most of the North American sink is located below $51^{\circ} \mathrm{N}$, south of the boreal forest zone (Fan et al., 1998). Land- and atmosphere-based studies have estimated that about half of the carbon sink in the United States is from nonforested areas (Pacala et al., 2001). However, land-based estimates have been unable to account for a large 
portion of the carbon sink identified by atmosphericbased studies. Though previous work has provided insight into the discrepancy between land- and atmosphere-based carbon sinks, land-based estimates need to be refined, especially for woody encroachment of western grasslands and for carbon storage in soils (Pacala et al., 2001). Woody encroachment was thought to increase carbon storage but the carbon sink previously attributed to woody encroachment of grassland has likely been overestimated because of reduced root biomass when shrubs replace grasses (Jackson et al., 2002). Thus, the location of specific terrestrial carbon sinks in North America and their capacity to sequester atmospheric carbon remains poorly defined.

The glaciated prairie pothole region (PPR) is a major nonforested landform in north-central North America (Fig. 1). The PPR is approximately $900,000 \mathrm{~km}^{2}$ (Mann, 1986; Phospahala et al., 1974) and may have contained over 20 million ha of wetlands prior to European settlement (Millar, 1989; Tiner, 1984). Soils in the PPR are fertile and the area has been extensively developed for agriculture. Consequently, $>50 \%$ of the wetland area in the PPR of the United States (Tiner, 1984) and 71\% in Canada (Environment Canada, 1986) have been drained for agricultural development. Although ground-based sink studies have found cropland and grassland soils to be important for carbon storage (Lal et al., 1999), carbon storage in wetlands has not been evaluated. Wetlands make up $23 \%$ of the land area in the PPR, and they are important components of the global ecosystem, performing many important functions, including carbon cycling (Mitsch and Gosselink, 2000). Extensive conversion of PPR wetlands for agricultural production has stimulated considerable interest in restoring previously farmed wetlands for conservation purposes (Knutsen and Euliss, 2001). To determine the impact of this practice on the storage of atmospheric carbon, we compared the soil organic carbon content of undisturbed PPR wetlands to those with a previous history of cultivation. We also calculated a regional estimate of the potential carbon storage in wetlands because the PPR is within the zone (i.e., below $51^{\circ} \mathrm{N}$ ) thought to represent a large

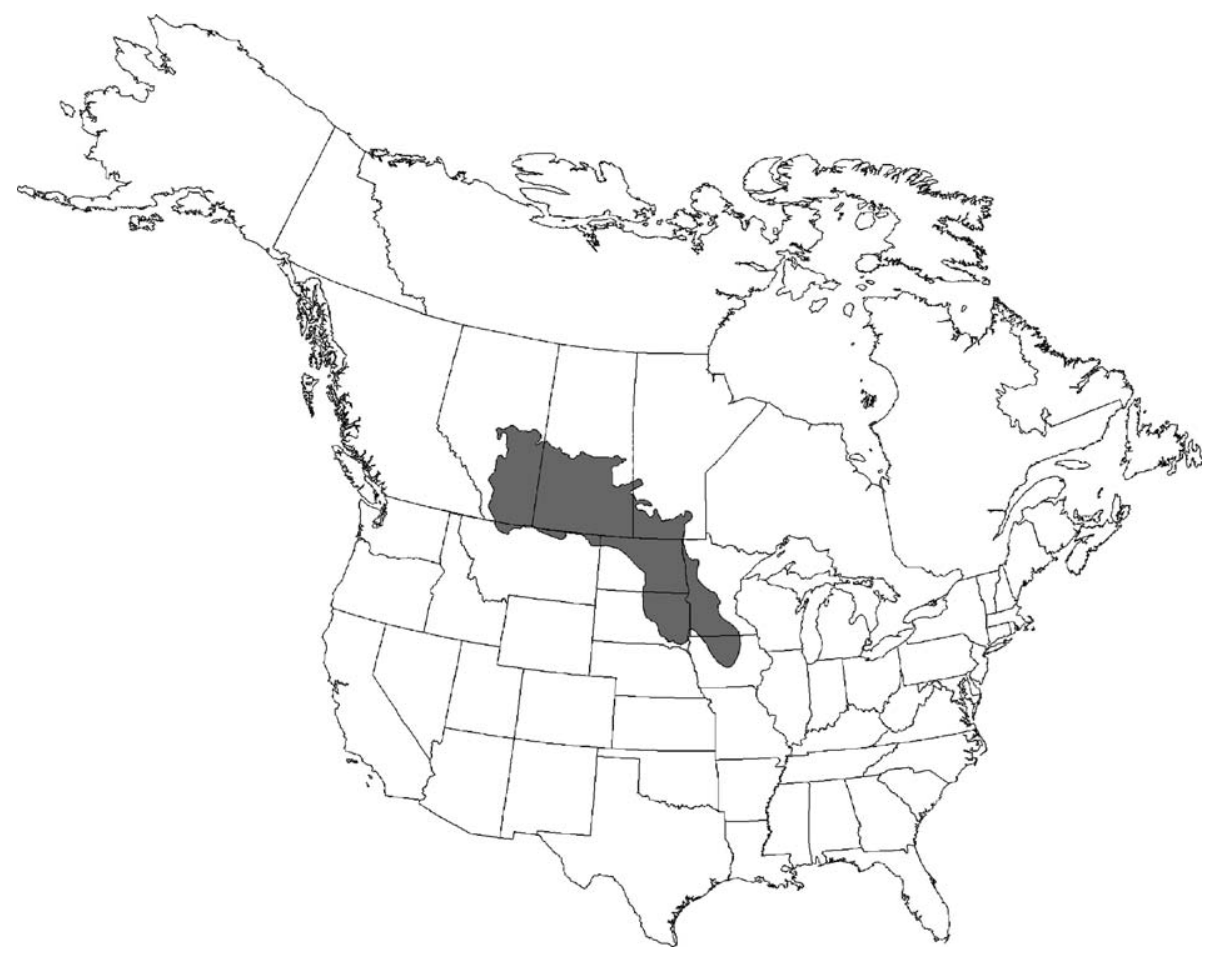

Fig. 1. The prairie pothole region of North America. 


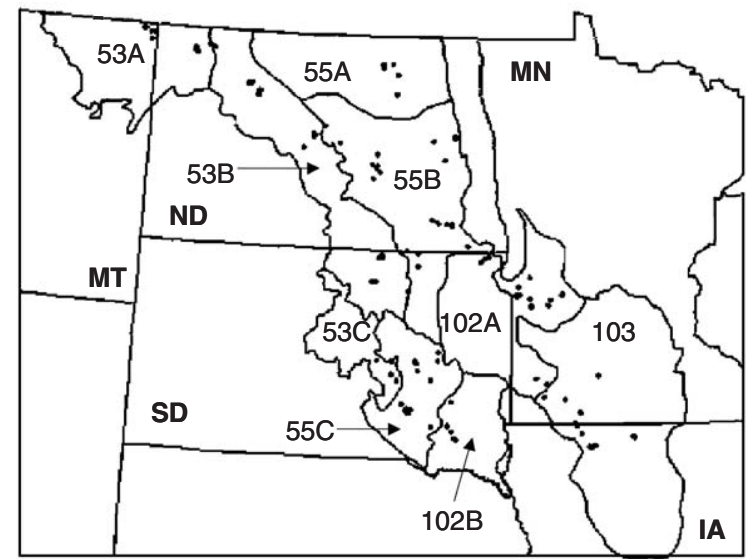

Fig. 2. Locations of wetlands sampled for soil organic carbon within Major Land Resource Areas (MLRAs) within the United States prairie pothole region. Coteau (terminal moraine) regions include MLRAs 53A, 53B, 55C, and 102B and the Glaciated W.B. Plains (ground moraine) includes MLRAs 55A, 55B, 102A, and 103.

terrestrial carbon sink (Fan et al., 1998). We compared this regional estimate of potential carbon storage that would occur by restoring previously farmed wetlands to an estimate of converting all agricultural cropland in the region to no-till management. Since it is unlikely that either land-use change would be fully implemented, we also compared rates of carbon sequestration in restored wetlands to that of no-till cropland.

\section{Methods}

\subsection{Experimental design and soil sampling}

Field measurements of soil organic carbon were made in 174 wetlands in the United States PPR that included the glaciated portions of Montana, North and South Dakota, Minnesota, and Iowa (Fig. 2). We used a systematic sampling design stratified by physiographic region (i.e., Coteau and Glaciated Plains; allocation of sampling points was proportional to the linear length of each physiographic region) to select representative random wetlands along the northwestto-southeast climatic and land-use gradients in the PPR. Near each sampling point $(n=21)$, we selected one seasonal and one semipermanent palustrine emergent depressional wetland (Cowardin et al., 1979) in each of the following land-use categories: (1) restored wetlands $<5$ years old in the U.S. Department of Agriculture's (USDA) Conservation Reserve Program (CRP) or similar grasslands (i.e., idled farmed land planted back to perennial grasses), (2) restored wetlands $>5$ years old in CRP-type habitats, (3) drained wetlands in CRP-type habitats, (4) nondrained wetlands in CRP-type habitats, and (5) reference wetlands in native grassland with no history of cultivation in the wetland basin or the surrounding catchment. We restricted the area of seasonal wetlands to $0.4-0.8$ ha and semipermanent wetlands to $2.5-5.5$ ha; area range selection criteria represented the mean basin size $( \pm 1$ standard deviation) of seasonal and semipermanent wetlands in North and South Dakota (National Wetland Inventory Data; see http://www.nwi.fws.gov). Ideally our sampling effort would have resulted in the selection of 210 wetlands (Table 1), but certain wetland categories were not available near every sampling point.

We collected soil samples along four randomly established transects that radiated from the wetland center to the outer edge of the wet-meadow zone (Stewart and Kantrud, 1971). We collected soil samples to a depth of $30 \mathrm{~cm}$ from each vegetative zone (i.e., wet-meadow, shallow-marsh, and deep-marsh zones) bisected by transects. Samples from each zone within a wetland were composited by 0 to 15 and 15 to $30 \mathrm{~cm}$ depth increments. On a subsample of wetlands $(n=70)$, we collected soil cores to a depth of $30 \mathrm{~cm}$ for bulk density (total solids per unit volume; $\mathrm{g}$ $\mathrm{cm}^{-3}$ ) determination from the wet-meadow and shallow-marsh zones. We determined total $\mathrm{C}$ with a LECO model CN2000 analyzer (LECO Corporation, 1994a,b) and inorganic C using the volumetric meth-

Table 1

Wetlands sampled for soil organic carbon in the United States prairie pothole region in 1997

\begin{tabular}{lllll}
\hline Wetland class $^{\mathrm{a}}$ & \multicolumn{2}{l}{ Treatments $^{\mathrm{b}}$} & & \\
\cline { 2 - 5 } & Reference & Nondrained & Restored & Drained \\
\hline Seasonal & 21 & 21 & 38 & 19 \\
Semipermanent & 19 & 17 & 27 & 12 \\
\hline
\end{tabular}

${ }^{a}$ Wetland classification according to Cowardin et al. (1979).

${ }^{b}$ Reference wetlands have no history of cultivation in their wetland basin or surrounding catchments; nondrained, restored, and drained wetlands have a history of cultivation and are in Conservation Reserve Program (CRP) or similar grasslands (i.e., prior farmed lands planted back to perennial cover). 
Table 2

Regression equations used to predict bulk density from organic carbon concentration

\begin{tabular}{|c|c|c|c|c|c|c|}
\hline Wetland class & Wetland zone $\mathrm{e}^{\mathrm{a}}$ & Depth $(\mathrm{cm})$ & $n$ & Regression equation $^{\mathrm{b}}$ & $r^{2}$ & $P$ value \\
\hline Seasonal & WM & $0-15$ & 38 & $1.3433-0.0713 \times \mathrm{OC}$ & 0.25 & 0.0015 \\
\hline Seasonal & WM & $15-30$ & 38 & $1.3652-0.0781 \times \mathrm{OC}$ & 0.23 & 0.0021 \\
\hline Seasonal & SM & $0-15$ & 38 & $1.3596-0.0901 \times \mathrm{OC}$ & 0.64 & $<0.0001$ \\
\hline Seasonal & SM & $15-30$ & 38 & $1.4588-0.0105 \times \mathrm{OC}$ & 0.42 & $<0.0001$ \\
\hline Semipermanent & WM & $0-15$ & 32 & $1.3030-0.0637 \times \mathrm{OC}$ & 0.34 & 0.0005 \\
\hline Semipermanent & WM & $15-30$ & 32 & $1.3932-0.0945 \times \mathrm{OC}$ & 0.33 & 0.0006 \\
\hline Semipermanent & $\mathrm{SM}, \mathrm{DM}^{\mathrm{c}}$ & $0-15$ & 32 & $1.1747-0.0517 \times \mathrm{OC}$ & 0.16 & 0.0243 \\
\hline Semipermanent & SM, DM & $15-30$ & 32 & $1.3926-0.0820 \times \mathrm{OC}$ & 0.31 & 0.0009 \\
\hline
\end{tabular}

${ }^{\mathrm{a}} \mathrm{WM}=$ Wet Meadow; $\mathrm{SM}=$ Shallow Marsh; DM=Deep Marsh.

${ }^{\mathrm{b}} \mathrm{OC}=$ Organic Carbon concentration.

${ }^{c}$ Equation derived from shallow-marsh zone was used to predict bulk density for deep-marsh zone.

od of Wagner et al. (1988). Organic C was determined as the difference between total $\mathrm{C}$ and inorganic $\mathrm{C}$. Organic $\mathrm{C}$ concentration for each wetland was adjusted for soil bulk density to estimate $\mathrm{Mg} \mathrm{OC} \mathrm{ha-1} \mathrm{for}$ each depth increment and vegetative zone. For wetlands where bulk density was not directly measured, we estimated bulk density from the regression relationship between bulk density and carbon concentration (Table 2). We calculated percent area (ha) of wetland zones from a total station topographic survey of each wetland. Carbon estimates for each zone were weighted (i.e., multiplied) by percent zone area and summed to provide an estimate of $\mathrm{Mg} \mathrm{OC} \mathrm{ha}^{-1}$ for each depth increment.

Analysis of carbon estimates indicated that carbon content only differed in the surface $15 \mathrm{~cm}$ with greater carbon in reference wetlands than in previously farmed wetland categories (i.e., drained, restored, and nondrained wetlands; Table 3). Since carbon did not differ among wetlands with a farmed history, we combined these wetland types into a single category, called 'farmed' wetlands (Table 4).

\subsection{Estimating wetland carbon stores in the United States and Canada}

To estimate regional carbon stores, we applied our estimates of carbon stores in natural and restored wetlands to land use and area estimates for the United States and Canada. We used the 1997 National Resources Inventory (NRI; U.S. Department of Agriculture, 2000) data to estimate wetland and upland areas by broad land-use category within each Major Land Resource Area (MLRA; U.S. Department of Agriculture, 1981) (Fig. 2) in the United States PPR. To estimate wetland and upland areas by land-use category in the PPR of Canada, we overlayed the Canadian wetland inventory (Ducks Unlimited Canada, 1986) and land cover data (Prairie Farm Rehabilitation Administration, 1995). Unlike the NRI database, the Ducks Unlimited Canada (1986) wetland inventory lacks estimates of drained wetlands. Estimates of wetlands altered or lost due to agricultural drainage in the Canadian PPR range from $71 \%$ to $75 \%$ (Environment Canada, 1986;

Table 3

Comparison of soil organic carbon $\left(\mathrm{Mg} \mathrm{ha}^{-1}\right)$ among treatments by depth for 174 wetlands in the prairie pothole region of the United States, 1997

\begin{tabular}{|c|c|c|c|c|c|c|}
\hline \multirow[t]{2}{*}{ Treatment } & \multicolumn{2}{|c|}{0 to $15 \mathrm{~cm}^{\mathrm{a}}$} & \multicolumn{2}{|c|}{15 to $30 \mathrm{~cm}^{\mathrm{b}}$} & \multicolumn{2}{|c|}{0 to $30 \mathrm{~cm}^{\mathrm{c}}$} \\
\hline & Mean & 95\% C.I. & Mean & $95 \%$ C.I. & Mean & 95\% C.I. \\
\hline Drained & $51.9^{1}$ & $(46.4-57.4)$ & $47.2^{1}$ & $(42.2-52.1)$ & $99.1^{1}$ & $(89.4-108.7)$ \\
\hline Nondrained & $52.6^{1}$ & $(47.6-57.5)$ & $43.7^{1}$ & $(39.2-48.2)$ & $96.3^{1}$ & $(87.5-105.0)$ \\
\hline Restored & $51.9^{1}$ & $(48.1-55.7)$ & $44.6^{1}$ & $(41.2-48.0)$ & $96.5^{1}$ & (89.8-103.2) \\
\hline Reference & $62.2^{2}$ & $(57.4-67.1)$ & $43.9^{1}$ & $(39.5-48.2)$ & $106.1^{1}$ & (97.6-114.6) \\
\hline
\end{tabular}

Means within column followed by a common number are not significantly different $(P<0.05)$.

ANOVA model probabilities for treatment main effects: ${ }^{\mathrm{a}}\left(F_{3,170}=4.41, P=0.005\right),{ }^{\mathrm{b}}\left(F_{3,170}=0.43, P=0.729\right),{ }^{\mathrm{c}}\left(F_{3,170}=1.21, P=0.309\right)$ 
Table 4

Comparison of soil organic carbon $\left(\mathrm{Mg} \mathrm{ha}^{-1}\right)$ among farmed and reference wetlands by depth for 174 wetlands in the prairie pothole region of the United States, 1997

\begin{tabular}{|c|c|c|c|c|c|c|}
\hline \multirow[t]{2}{*}{ Treatment } & \multicolumn{2}{|c|}{0 to $15 \mathrm{~cm}^{\mathrm{a}}$} & \multicolumn{2}{|c|}{15 to $30 \mathrm{~cm}^{\mathrm{b}}$} & \multicolumn{2}{|c|}{0 to $30 \mathrm{~cm}^{\mathrm{c}}$} \\
\hline & Mean & 95\% C.I. & Mean & 95\% C.I. & Mean & 95\% C.I. \\
\hline Farmed & $52.1^{1}$ & $(49.5-54.7)$ & $44.9^{1}$ & $(42.6-47.3)$ & $97.0^{1}$ & $(92.4-101.7)$ \\
\hline Reference & $62.2^{2}$ & $(57.4-67.1)$ & $43.9^{1}$ & $(39.5-48.2)$ & $106.1^{1}$ & (97.6-114.6) \\
\hline
\end{tabular}

Means within column followed by a common number are not significantly different $(P<0.05)$.

ANOVA model probabilities for treatment main effects: ${ }^{\mathrm{a}}\left(F_{1,172}=13.3, P=0.0003\right),{ }^{\mathrm{b}}\left(F_{1,172}=0.19, P=0.667\right),{ }^{\mathrm{c}}\left(F_{1}, 172=3.44, P=0.065\right)$.

Young, 1994). To adjust for losses not accounted for in the wetland inventory, we assumed a conservative $71 \%$ wetland loss. The wetland area estimate, unadjusted for wetland loss, indicated that $42.5 \%$ of the total wetland area in the PPR occurred in Canada; hence, the adjusted estimate of $71.8 \%$ is more reasonable because $67.5 \%$ of the PPR occurs in Canada (Table 5).

Organic soil carbon estimates for the surface $15 \mathrm{~cm}$ of farmed and reference wetlands (i.e., wetlands with no prior history of cultivation) we sampled within each MLRA were averaged and used to estimate carbon stores of palustrine wetland soils (Table 6). For palustrine wetlands in cropland and in restored grassland (e.g., U.S. Department of Agriculture's Conservation Reserve Program), farmed wetland carbon estimates were used to estimate current carbon stores, and reference wetland estimates were used to estimate historic carbon stores. To estimate carbon stores in wetland soil in the Canadian PPR, we applied our estimates of average carbon stores in reference and farmed wetlands in the United States (Table 7) to wetland areas in Canada.

\section{Results}

\subsection{Potential carbon storage in restored wetlands}

To estimate the carbon storage potential of wetland restoration activities, we projected, over a 10-year period, the amount of carbon that would be stored if all cropland wetlands were restored in the PPR. We considered three types of carbon storage processes: (a) replenishment of soil carbon in the $0-15 \mathrm{~cm}$ soil profile, (b) carbon stored by mass accumulation of sediments, and (c) carbon stored in the living plant community. Analysis of carbon estimates demonstrated that, relative to reference wetlands, farmed wetlands have lost on average $10.1(95 \%$ C.I. $=4.7$ to 15.6) $\mathrm{Mg} \mathrm{OC} \mathrm{ha}^{-1}$ in the surface $15 \mathrm{~cm}$ of soil (Table 4). Our research also showed that when semipermanent wetlands (Stewart and Kantrud, 1971) are restored, carbon in the surface $15 \mathrm{~cm}$ is replenished at a rate of $3.05 \mathrm{Mg} \mathrm{OC} \mathrm{ha}{ }^{-1}$ year $^{-1}$ (Fig. 3). Based on this rate of increase, it would take an average of 3.3 years $(95 \%$ C.I. $=1.5$ to 5.1$)$ for carbon lost in the surface $15 \mathrm{~cm}$ due to cultivation to be replenished

Table 5

Terrestrial and aquatic areas in the prairie pothole region of North America

\begin{tabular}{|c|c|c|c|c|c|}
\hline \multirow[t]{2}{*}{ System } & \multirow[t]{2}{*}{ U.S. PPR, $10^{3}$ ha (SE) } & \multirow[t]{2}{*}{ Canada PPR, $10^{3}$ ha } & \multirow[t]{2}{*}{ Total PPR, $10^{3}$ ha } & \multicolumn{2}{|c|}{ Percent of total area $\left(10^{3} \mathrm{ha}\right)$} \\
\hline & & & & U.S. & Canada \\
\hline Palustrine & $5678(63.6)$ & 2635 & 8313 & 68.3 & 31.7 \\
\hline Lacustrine & $543(4.3)$ & 1959 & 2502 & 21.7 & 78.3 \\
\hline Subtotal & $6221(64.3)$ & 4594 & 10,815 & 57.5 & 42.5 \\
\hline $71 \% \operatorname{loss}^{\mathrm{a}}$ & na & 11,247 & na & na & na \\
\hline Total aquatic & $6221(64.3)$ & 15,841 & 22,062 & 28.2 & 71.8 \\
\hline Terrestrial & $24,239(101.7)$ & $47,433^{\mathrm{b}}$ & 71,672 & 33.8 & 66.2 \\
\hline Grand total & $30,460(93.3)^{\mathrm{c}}$ & 63,274 & 93,734 & 32.5 & 67.5 \\
\hline
\end{tabular}

\footnotetext{
${ }^{a}$ Estimate of drained or altered wetlands in Canada not accounted for by Ducks Unlimited Canada (1986). This estimate assumes that the wetland area accounted for in the inventory (i.e., subtotal $=4594$ ) represent only $29 \%$ (Environment Canada, 1986) of the original wetlands.

b Terrestrial area $(58,680)$ minus the estimated drained wetland area $(11,247)$ not accounted for by Ducks Unlimited Canada $(1986)$.

${ }^{\mathrm{c}}$ Does not include riverine wetlands $\left(132 \times 10^{3}\right.$ ha) or Federal land $\left(347 \times 10^{3}\right.$ ha).
} 
Table 6

Estimate of soil organic carbon $\left(\mathrm{Mg} \mathrm{ha}^{-1}\right)$ in the surface $15 \mathrm{~cm}$ of farmed and reference wetlands within Major Land Resource Areas (U.S. Department of Agriculture, 1981) within the prairie pothole region of the United States

\begin{tabular}{llllllll}
\hline MLRAs & \multicolumn{2}{l}{ Farmed wetlands } & & & \multicolumn{3}{c}{ Reference wetlands } \\
\cline { 2 - 3 } & Mean & $95 \%$ C.I. & \multicolumn{1}{c}{$n$} & & Mean & $95 \%$ C.I. & $n$ \\
\hline 102A & 48.1 & $(40.9-55.2)$ & 16 & & 73.4 & $(54.6-92.3)$ & 4 \\
102B & 36.4 & $(32.4-40.4)$ & 5 & & 38.9 & $(15.5-62.3)$ & 2 \\
103 & 56.2 & $(48.6-63.9)$ & 20 & 76.7 & $(70.0-83.5)$ & 7 \\
53A & 58.2 & $(47.9-68.6)$ & 15 & 59.1 & $(26.3-92.0)$ & 4 \\
53B & 58.0 & $(52.4-63.7)$ & 27 & 59.1 & $(42.6-75.6)$ & 10 \\
53C & 50.9 & $(44.4-57.5)$ & 7 & 54.9 & $(00.0-132.6)$ & 2 \\
55A & 54.3 & $(46.7-61.9)$ & 8 & 62.3 & $(00.0-150.4)$ & 2 \\
55B & 48.9 & $(43.5-54.4)$ & 21 & 67.5 & $(61.0-74.0)$ & 5 \\
55C & 43.0 & $(35.7-50.4)$ & 15 & 45.4 & $(29.8-61.0)$ & 4 \\
\hline
\end{tabular}

through restoration. Reference seasonal wetlands (Stewart and Kantrud, 1971) had significantly more organic carbon in the upper $15-\mathrm{cm}$ of soil $(63.5 \mathrm{Mg}$ $\left.\mathrm{OC} \mathrm{ha}^{-1}\right)$ than farmed seasonal wetlands $(51.9 \mathrm{Mg}$ OC ha $\left.{ }^{-1} ; F 1,97=10.7, P=0.0015\right)$. However, we were unable to detect a temporal increase in soil carbon for restored seasonal wetlands, a wetland class with short hydroperiods that is dry more often than semipermanent wetlands on a seasonal and interannual basis. This finding suggests that our sample size or the temporal replication was inadequate to detect the increase in soil carbon in seasonal wetlands. Because NRI lumps wetland water regimes into a single category (i.e., palustrine versus seasonal or semipermanent), we assumed that carbon stocks in

Table 7

Estimate of historic and potential carbon storage $(\mathrm{Tg})$ in cropland and wetland in the prairie pothole region of North America

\begin{tabular}{|c|c|c|c|c|c|c|c|c|}
\hline \multirow{2}{*}{$\begin{array}{l}\text { System/country } \\
\text { land cover }\end{array}$} & \multirow{2}{*}{$\begin{array}{l}\text { Area }^{\mathrm{a}} 10^{3} \\
\text { ha }(\mathrm{SE})\end{array}$} & \multicolumn{2}{|c|}{ OC Stores $^{\mathrm{b}}$} & \multirow{2}{*}{$\begin{array}{l}\text { Historic }^{c} \text { OC } \\
\text { loss (SE) }\end{array}$} & \multirow{2}{*}{$\begin{array}{l}\text { OC gain }{ }^{\mathrm{d}} \\
\text { (first } 5 \text { years) }\end{array}$} & \multirow{2}{*}{$\begin{array}{l}\text { OC gain } \\
\text { (next } 5 \text { years) }\end{array}$} & \multirow{2}{*}{$\begin{array}{l}\mathrm{OC}^{\mathrm{f}} \\
\text { standing } \\
\text { crop }\end{array}$} & \multirow{2}{*}{$\begin{array}{l}\text { OC gain } \\
\text { (10 year } \\
\text { total) }\end{array}$} \\
\hline & & $\begin{array}{l}\text { Past } \\
\text { (SE) }\end{array}$ & $\begin{array}{l}\text { Present } \\
\text { (SE) }\end{array}$ & & & & & \\
\hline \multicolumn{9}{|l|}{ Terrestrial/USA } \\
\hline Cropland & $16,129(112.6)$ & 1037 & 726 & 311 & 36 & 36 & na & 72 \\
\hline Other & $8,110(92.3)$ & & & & & & & \\
\hline \multicolumn{9}{|l|}{ Terrestrial/Canada } \\
\hline Cropland & 17,958 & 1128 & 790 & 338 & 40 & 40 & na & 80 \\
\hline Other & 29,475 & & & & & & & \\
\hline Total terrestrial & 71,672 & 2165 & 1516 & 649 & 76 & 76 & na & 152 \\
\hline \multicolumn{9}{|l|}{ Aquatic/USA } \\
\hline $\begin{array}{l}\text { Cropland } \\
\text { wetland }\end{array}$ & $3844(50.7)$ & $281(9.0)$ & 209 (10.7) & $72(14.0)$ & 72 & 16 & 27 & 115 \\
\hline Other & $2377(39.3)$ & & & & & & & \\
\hline \multicolumn{9}{|l|}{ Aquatic/Canada } \\
\hline Cropland Wetland & 12,400 & $771(34.3)$ & $646(15.8)$ & $125(37.8)$ & 125 & 51 & 87 & 263 \\
\hline Other & 3441 & & & & & & & \\
\hline Total aquatic & 22,062 & 1052 & 855 & 197 & 197 & 67 & 114 & 378 \\
\hline
\end{tabular}

${ }^{a}$ Area by system (terrestrial and aquatic) and land-use (cropland and other) in the USA based on the National Resources Inventory data (U.S. Department of Agriculture, 2000), and for Canada, the Ducks Unlimited wetland inventory (Ducks Unlimited Canada, 1986) and Prairie Farm Rehabilitation Administration land cover data (Prairie Farm Rehabilitation Administration, 1995). Land cover within "other" includes: native and non-native grasslands, forests, other non-cultivated lands, and $66 \times 10^{3}$ ha of cultivated cropland with incomplete soil records to estimate carbon stores.

${ }^{\mathrm{b}}$ Baseline estimates (i.e., present stores) of carbon in croplands of the USA and Canada were estimated using 1997 NRI data and the Canadian Soil Organic Database (Lacelle, 1996). Past stores (prior to cultivation) were estimated by assuming a 30\% loss of carbon (e.g., present stores/ 0.7). Present and past stores in cropland wetlands were estimated using information presented in this paper.

${ }^{c}$ Loss of carbon due to agricultural cultivation (past stores-present stores).

${ }^{\mathrm{d}}$ Expected increase in carbon in the surface $15 \mathrm{~cm}$ after 5 years if cropland was placed in no-till (assumes a $1 \%$ annual increase) and expected increase if cropland wetlands were restored (based on information presented in this paper).

${ }^{\mathrm{e}}$ Increase in carbon for cropland based on the same relationship as during the first 5 years. For wetlands, increase represents mass accumulation of carbon $\left(0.830 \mathrm{Mg} \mathrm{OC} \mathrm{ha-1}\right.$ year $\left.^{-1}\right)$ for 5 years

${ }^{\mathrm{f}}$ Carbon stored in developing plant community of restored wetlands (based on $7 \mathrm{Mg} \mathrm{OC} \mathrm{ha}{ }^{-1}$ ). This is not applicable (Na) to cropland in notill because annual crop produced is harvested.

${ }^{g}$ Expected total carbon stored after 10 years if all cropland was placed in no-till and all cropland wetlands were restored. 

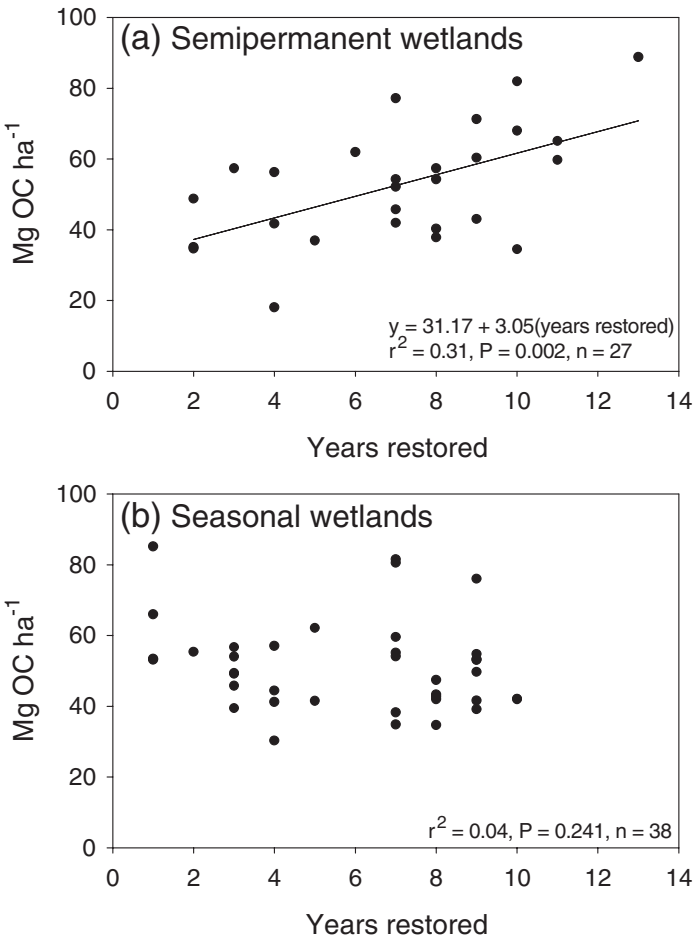

Fig. 3. Relationship between soil organic carbon in the surface 15 $\mathrm{cm}$ and years restored for (a) semipermanent and (b) seasonal wetlands.

all palustrine wetlands would return to reference condition within 5 years. Based on this assumption, restoration of all cropland wetlands would result in the storage of $197 \mathrm{Tg}$ of soil organic carbon during the first 5 years following restoration (Table 7).

We estimated mass accumulation of carbon in reference wetland soil at $0.830 \mathrm{Mg} \mathrm{ha}^{-1}$ year $^{-1}$ based on an average sedimentation rate of $2 \mathrm{~mm}$ year $^{-1}$ (Gleason, 2001) and a carbon content of $62.2 \mathrm{Mg} \mathrm{ha}{ }^{-1}$ we found in reference wetlands (Table 4). We assumed that restored farmed wetlands develop mass accumulation rates similar to reference wetlands; hence, in years 5-10 post-restoration, an additional $67 \mathrm{Tg}$ of carbon would be sequestered (Table 7). Finally, the vegetative community that develops in restored wetlands represents an additional pool of carbon. Above and below ground annual biomass of plants in wetlands range from 7 to 17 Mg OC ha ${ }^{-1}$ (McDougal, 2001; Wetzel, 2001); however, much of the below ground biomass likely contributes to the soil organic carbon pool. Hence, we used the estimate of $7 \mathrm{Mg} \mathrm{OC} \mathrm{ha}{ }^{-1}$ for above ground biomass and estimated that $114 \mathrm{Tg}$ of carbon would be associated with the standing crop of wetland vegetation (Table 7). In total, $378 \mathrm{Tg}$ of organic carbon can potentially be stored in the soil, sediment accumulation, and in the plant community of restored wetlands over a 10 -year period.

\subsection{Potential carbon storage in upland}

We used the 1997 NRI database and methods described in Lal et al. $(1995,1998)$ to estimate potential organic carbon storage under no-till management in the upper $15 \mathrm{~cm}$ of cropland soil within MLRAs in the United States PPR. We used these baseline estimates of organic carbon in cropland to project past and potential land-management scenarios. The literature indicates that $20 \%$ to $>50 \%$ of the organic carbon of native prairie is lost when converted to cultivated agriculture (Mann, 1986; Cihacek and Ulmer, 1995). Assuming that, on average, cultivation has resulted in a $30 \%$ loss of carbon, cropland in the United States PPR has lost $311 \mathrm{Tg}$ of organic carbon (Table 7). Converting conventionally farmed cropland to no-till agriculture would increase soil carbon by about $1 \%$ year ${ }^{-1}$ or 200 to $300 \mathrm{~kg} \mathrm{C}^{-1}$ year $^{-1}$ (Lal et al., 1998). Using this annual rate of increase, we estimated that $72 \mathrm{Tg}$ of carbon would be stored over a 10 -year period if all cropland in the United States PPR was converted to no-till management (Table 7).

To make similar calculations for Canadian cropland, we used the Canadian Soil Organic Carbon Database (CSOCD) (Lacelle, 1996), in combination with the Canadian land cover data (Prairie Farm Rehabilitation Administration, 1995), to estimate the carbon storage in cropland by broad land-use category. The CSOCD database includes surface soil carbon estimates to a $30-\mathrm{cm}$ depth. Studies indicate that approximately $55 \%$ to $60 \%$ of the organic carbon content within the surface $30 \mathrm{~cm}$ occurs in the upper $15 \mathrm{~cm}$ (Gebhart et al., 1994; Follett et al., 1997). Because the CSOCD database is for the surface 30 $\mathrm{cm}$, we estimated carbon in the surface $15 \mathrm{~cm}$ by multiplying carbon estimates within each land-use category by 0.57 . We then applied the procedures we used for the United States PPR to estimate carbon loss in cropland (338 $\mathrm{Tg}$ ) and carbon potentially stored $(80 \mathrm{Tg})$ by conversion to no-till agriculture in 
Canada (Table 7). In total, we estimate that $152 \mathrm{Tg}$ of soil organic carbon could be sequestered under no-till management in the PPR of the United States and Canada.

\section{Discussion and conclusions}

Numerous carbon sinks contribute to overall storage of atmospheric $\mathrm{CO}_{2}$ in the terrestrial Biosphere (Pacala et al., 2001) and current research is focused on the identification and management potential of a diversity of sinks, both biological and geological. Our study demonstrates that prairie wetlands are an important and previously overlooked biological carbon sink in North America. The finding that prairie wetlands have the potential to sequester more than twice as much carbon as conversion of all cropland to no-till agriculture (378 Tg versus $152 \mathrm{Tg}$; Table 7) is especially significant because cropland wetlands comprise only $17 \%$ of the land area. Wetlands are the most productive terrestrial ecosystem in the Biosphere (Whittaker and Likens, 1973). Although it is highly unlikely that wetland restoration or no-till agriculture will be fully implemented in the PPR, our results show that the rate of carbon recovery in prairie wetlands is especially high relative to projections for notill cropland. On a global scale, wetlands comprise the largest pool of stored carbon, representing 33\% of the soil organic matter on only about $4 \%$ of the land surface area (Eswaran et al., 1993). Cropland in the PPR has been depleted of organic matter through conventional agriculture (Mann, 1986; Lal et al., 1995; Cihacek and Ulmer, 1995) and the rate of sequestration is low under no-till agriculture, averaging about $1 \%$ annually (Lal et al., 1998). However, no-till is the most effective means of sequestering carbon in cropland while maintaining crop production (Lal et al., 2004).

While prairie wetlands are important for carbon storage, there are valid concerns over the release of greenhouse gases (GHG) such as methane $\left(\mathrm{CH}_{4}\right)$ and nitrous oxide $\left(\mathrm{N}_{2} \mathrm{O}\right)$. Wetlands appear to be the largest source of $\mathrm{CH}_{4}$, contributing about $20 \%$ of the annual global emission to the atmosphere (Wang et al., 1996). Methane is a very potent GHG with a global warming potential (GWP) of 21 (Intergovernmental Panel on Climate Change, 1996), and it is naturally emitted by wetlands (Mitsch and Gosselink, 2000). Nitrous oxide is an even more potent GHG with a GWP of 310 (Intergovernmental Panel on Climate Change, 1996) and it persists about as long as $\mathrm{CO}_{2}$ in the atmosphere, approximately 120 years whereas $\mathrm{CH}_{4}$ only lasts for 12-15 years (U.S. Environmental Protection Agency, 2003). While nitrogen enrichment of ombrotrophic mires apparently has little or no effect on methane emission (Hutchin et al., 1996), data from a glaciated region in northeastern Germany similar to the North American PPR suggest that enrichment from nitrogen fertilizers and accelerated mineralization of soil organic matter elevate the emission of $\mathrm{CH}_{4}$ and $\mathrm{N}_{2} \mathrm{O}$ (Merbach et al., 2002). Findings from Germany are consistent with other studies that demonstrate that nitrogen fertilization enhances emission of $\mathrm{N}_{2} \mathrm{O}$ (Thornton and Valente, 1996; Davidson et al., 2000).

Restored wetlands in North America are generally sited within marginal farmlands that have been voluntarily idled by private landowners (e.g., Conservation Reserve Program of the U.S. Farm Bill) and reseeded to perennial grasses; hence, they receive little or no enrichment from agricultural fertilizers. In comparison, most remaining wetlands in the PPR are situated within agricultural fields where they are farmed except during extremely wet periods. Hence, most wetlands in the PPR at the current time receive runoff from surrounding agricultural areas that have been shown to exacerbate $\mathrm{CH}_{4}$ and $\mathrm{N}_{2} \mathrm{O}$ emission rates (Merbach et al., 2002). Consequently, converting cultivated cropland to perennial vegetation within restored wetland catchments should reduce nutrient enrichment in restored wetlands and lower emissions of $\mathrm{N}_{2} \mathrm{O}$, and possibly $\mathrm{CH}_{4}$ from wetland basins. Further, the conversion of cropland to perennial grassland has been shown to reduce $\mathrm{CH}_{4}$ emission from upland soils (Keller et al., 1990; Dorr et al., 1993; Dobbie and Smith, 1994; Parashar et al., 2001). Hence, the conversion of cropland to perennial grassland when wetlands are restored should reduce overall $\mathrm{CH}_{4}$ emission.

Our results are consistent with the literature that cultivation is the most important factor in soil carbon loss (Lal et al., 2004). However, the restoration of wetland hydrology (e.g., plugging artificial drains) also is a critical component of restoration. The fact that carbon storage is enhanced under anoxic conditions is important because flooded wetlands provide 
optimal conditions for accretion of organic matter. Our study suggests that the overall organic carbon content of prairie wetlands is comparable to native grasslands (Blank and Fosberg, 1989), but the rate of carbon sequestration is approximately five times higher in restored wetlands than restored grassland (Follett et al., 2001). Upland catchment areas, normally re-vegetated when wetlands are restored, clearly provide additional carbon storage. The rate of carbon sequestration in wetlands will decrease over time as carbon storage in restored wetlands replenishes lost carbon stores. Carbon accretion in restored grassland proceeds slowly, but overall storage should exceed that of wetland soils because it comprises a substantially larger land area. Reduction in GHG emission in restored wetlands should provide long-term GHG reduction benefits; GHG emissions associated with the previous agricultural land-use change should be reduced.

The annual fossil $\mathrm{CO}_{2}$ emission for North America in 1990 was 1.6 Pg C (Fan et al., 1998). Hence, wetlands in the PPR of North America have potential to offset $2.4 \%$ of the annual fossil $\mathrm{CO}_{2}$ emissions over a 10 -year period. This estimate may be low because detailed information on carbon loss by major land areas was not available for Canada. Multiplying our estimate of $10.1 \mathrm{Mg} \mathrm{OC} \mathrm{ha}{ }^{-1}$ for mean carbon loss for cropped wetlands in the United States by the area of cropped wetlands in the United States and Canada (Table 4) suggests that $38 \mathrm{Tg}$ and $125 \mathrm{Tg}$ of organic carbon have been lost from wetlands in the United States and Canada, respectively. However, the $72 \mathrm{Tg}$ loss we report for the United States (Table 4) accounted for spatial variation in carbon loss associated with specific MLRAs that ranged from $<1$ to 25 $\mathrm{Mg} \mathrm{ha}{ }^{-1}$ (Table 1). In contrast, our estimate for Canada did not account for differences in climate, precipitation, and land-use that vary spatially and influence soil organic carbon content.

The most recent inventory of GHG emissions and sinks for the United States (U.S. Environmental Protection Agency, 2003) reported restored prairie wetlands as carbon sinks but our study is the first to document the magnitude of this sink. Much additional research is needed to refine our estimates of sink size and its overall importance. Specific information on carbon loss within major land-use areas in prairie Canada is needed to fully assess the overall size of this carbon sink. Further, research on other wetland types and relationships of grassy buffer to GHG emissions will be required before optimal land-use strategies can be developed to help mitigate global climate change.

\section{Acknowledgements}

We thank S.P. Brady, B.A. Browne, S.P. Faulkner, M.K. Laubhan, V. Lessard, D.W. Schindler, and M.R. Turetsky for providing comments on an earlier version of this manuscript.

\section{References}

Blank RR, Fosberg MA. Cultivated and adjacent virgin soils in northcentral South Dakota: I Chemical and physical comparisons. Soil Sci Soc Am J 1989;53:1484-90.

Ciais P, Tans PP, Trolier M, White JWC, Francey RJ. A large northern hemisphere $\mathrm{CO}_{2}$ sink indicated by the ${ }^{13} \mathrm{C} /{ }^{12} \mathrm{C}$ ratio of atmospheric $\mathrm{CO}_{2}$. Science 1995;269:1098-102.

Cihacek LJ, Ulmer MG. Estimated soil organic carbon losses from long-term crop-fallow in the Northern Great Plains of the USA. In: Lal R, Kimble JM, Levine E, Stewart BA, editors. Soil management and greenhouse effect. Boca Raton (FL): CRC Press; 1995. p. 85-92.

Cowardin LM, Carter V, Golet FC, La Roe ET. Classification of wetlands and deepwater habitats of the United States. US Fish and Wildlife Service Technological Report 17. Washington (DC): U.S. Government Printing Office; 1979. 131 pp.

Davidson EA, Keller M, Erickson HE, Verchot LV, Veldkamp E. Testing a conceptual model of soil emissions of nitrous and nitric oxides. Bioscience 2000;50:667-80.

Dobbie KE, Smith KA. Effect of land use on the rate of uptake of methane by surface soils in northern Europe. Ann Geophys Part II 1994;12(Suppl. II):C388.

Dorr H, Katruff L, Levine I. Soil texture parameterization of methane uptake in aerated soils. Chemosphere 1993;26:697-713.

Ducks Unlimited Canada. Habitat inventory program, based on classified Landsat 5 TM 1984-1995 imagery, 30 metre pixels; 1986.

Environment Canada. Wetlands in Canada: a valuable resource. Fact Sheet 86-4. Ottawa, Ontario: Lands Directorate; 1986.

Eswaran H, van der Berg E, Reich P. Organic carbon in soils of the world. Soil Sci Soc Am J 1993;57:192-4.

Fan S, Gloor M, Mahlman J, Pacala S, Sarmiento J, Takahashi T, et al. A large terrestrial carbon sink in North America implied by atmosphere and oceanic carbon dioxide data and models. Science 1998;282:442-6.

Follett RF, Paul EA, Leavitt SW, Halvorson AD, Lyon D, Peterson GA. Carbon isotope ratios of Great Plains soils and in wheatfallow systems. Soil Sci Soc Am J 1997;61:1068-77. 
Follett RF, Pruessner EG, Samson-Liebig SE, Kimble JM, Waltman SW. Carbon sequestration under the Conservation Reserve Program in the historic grassland soils of the United States of America. Soil Sci Soc Am J 2001;57:27-40.

Gebhart DL, Johnson HB, Mayeux HS, Polley HW. The CRP increases soil organic carbon. J Soil Water Conserv 1994; 49:488-92.

Gleason RA. Invertebrate egg and plant seed banks in natural, restored, and drained wetlands in the prairie pothole region (USA) and potential effects of sedimentation on recolonization of hydrophytes and aquatic invertebrates. PhD Dissertation. South Dakota State University, Brookings (SD); 2001, 154 pp.

Hutchin PR, Press MC, Lee JA, Ashenden TW. Methane emission rates from an ombrotrophic mire show marked seasonality which is independent of nitrogen supply and soil temperature. Atmos Environ 1996;30:3011-5.

Intergovernmental Panel on Climate Change. In: Houghton JT, Meira Filho LG, Callander BA, Harris N, Kattenberg A, Maskell K, editors. Climate change 1995: the science of climate change. Cambridge: Cambridge University Press; 1996. 572 pp.

Jackson RB, Benner JL, Jobbagy EG, Pockman WT, Wall DH. Ecosystem carbon loss with woody plant invasion of grasslands. Nature 2002;418:623-6.

Keller M, Mitre ME, Stallard RF. Consumption of atmospheric methane in soils in central Panama: effects of agricultural development. Glob Biogeochem Cycles 1990;4:21-7.

Knutsen GA, Euliss Jr NH. Wetland restoration in the prairie pothole region of North America: a literature review. Biological Science Report, USGS/BRD/BSR-2001-2006. Reston (VA): U.S. Geological Survey; 2001. p. 340.

Lacelle B. Canada's soil organic carbon database. Proceedings of the carbon sequestration in soil symposium, Columbus $(\mathrm{OH})$ : July 22-26; 1996.

Lal R, Kimble JM, Levine E, Stewart BA. Soils and global change. Boca Raton (FL): CRC Press; 1995. 440 pp.

Lal R, Kimble JM, Follett RF, Stewart BA. Management of carbon sequestration in soil. Boca Raton (FL): CRC Press; 1998. 457 pp.

Lal R, Kimble JM, Follet RF, Cole CV. The potential of US cropland to sequester carbon and mitigate the greenhouse effect. Boca Raton (FL): Lewis Publishers; 1999. 128 pp.

Lal R, Griffin M, Apt J, Lave L, Morgan MG. Managing soil carbon. Science 2004;304:393.

LECO Corporation. Instrumentation for: metals, energy, agriculture, geology, mining Applications bulletin. St. Joseph (MI): LECO Corp.; 1994a.

LECO Corporation. Total and organic carbon in soil, limestone and similar materials Applications bulletin. St. Joseph (MI): LECO Corp.; 1994b.

Mann LK. Changes in soil carbon storage after cultivation. Soil Sci 1986;42:279-88.

McDougal RL. Algal primary production in prairie wetlands: the effects of nutrients, irradiance, temperature and aquatic macrophytes. PhD Dissertation, Department of Botany, University of Manitoba, Winnipeg (MB); 2001. 290 pp.

Merbach W, Kalettka T, Rudat C, Augustin J. Trace gas emissions from riparian areas of small eutrophic inland waters in NortheastGermany. In: Broll, Merbach, Pfeiffer, editors. Wetlands in
Central Europe, soil organisms, soil ecological processes, and trace gas emissions. Berlin: Springer; 2002. p. 235-44.

Millar JB. Perspectives on the status of Canadian prairie wetlands. In: Sharitz RR, Gibbons JW, editors. US Department of Energy Symposium Series, Freshwater wetlands and wildlife, March 24-27, 1986, Oak Ridge (TN); 1989. p. 829-52.

Mitsch WJ, Gosselink JG. Wetlands. Third edition. New York (NY): Van Nostrand Reinhold; 2000. 920 pp.

Pacala SW, Hurtt GC, Baker D, Peylin P, Houghton RA, Birdsey RA, et al. Consistent land- and atmosphere-based U.S. carbon estimates. Science 2001;292:2316-20.

Parashar DC, Gupta PK, Sharma C. Estimate of methane uptake potential by Indian soils. Chemosphere Glob Chang Sci 2001;3:171-4.

Phospahala RS, Anderson DR, Henry CJ. Population ecology of the mallard. Resource Publication 115-U.S. Fish and Wildlife Service. Washington (DC): U.S. Government Printing Office; 1974. $74 \mathrm{pp}$.

Prairie Farm Rehabilitation Administration. Western Grain transition payment land cover data, based on classified Landsat 5 TM 1994-1995 imagery, 30/25 metre pixels; 1995.

Schimel DS, House JI, Hibbard KA, Bousquet P, Ciais P, Peylin P, et al. Recent patterns and mechanisms of carbon exchange by terrestrial ecosystems. Nature 2001;414:169-72.

Stewart RE, Kantrud HA. Classification of natural ponds and lakes in the glaciated prairie region. Resource Publication 92-US Fish and Wildlife Service. Washington (DC): U.S. Government Printing Office; $1971.57 \mathrm{pp}$.

Tans PP, Fung IY, Takahashi T. Observation constraints on the global $\mathrm{CO}_{2}$ budget. Science 1990;247:1431-8.

Thornton FC, Valente RJ. Soil emissions of nitrous oxide from notill corn. Soil Sci Soc Am J 1996;60:1127-33.

Tiner RW Jr. Wetlands of the United States: current status and recent trends. U.S. Fish and Wildlife Service, U.S. Government Printing Office, Washington (DC); 1984, 59 pp.

U.S. Department of Agriculture. Land resource regions and major land resource areas of the United States. Agricultural Handbook, vol. 296. Soil Conservation Service; 1981. 156 pp.

U.S. Department of Agriculture. Summary Report: 1997 National Resources Inventory (revised December 2000), Natural Resources Conservation Service, Washington, DC, and Statistical Laboratory, Iowa State University, Ames (IA); 2000. 89 pp.

U.S. Environmental Protection Agency. Inventory of US greenhouse gas emissions and sinks: 1990-2001. Washington (DC): U.S. Environmental Protection Agency; 2003. 596 pp.

Wagner SW, Hanson JD, Olness A, Vorhees WB. A volumetric inorganic carbon analysis system. Soil Sci Soc Am J 1988;62:690-3.

Wang Z, Dong Z, Patrick Jr WH. Methane emissions from natural wetlands. Environ Monit Assess 1996;42:143-61.

Wetzel RG. Limnology: lake and river ecosystems3rd edition. New York: Academic Press; 2001. 1006 pp.

Whittaker RH, Likens GE. Primary production: the Biosphere and man. Hum Ecol 1973;1:357-69.

Young DA. Wetlands are not wastelands: a study of functions and evaluation of Canadian wetlands. In: Mitsch WJ, editor. Global wetlands: old world and new. Amsterdam: Elsevier Science; 1994. p. $683-9$. 